\title{
Utilization of Exact Methods within Decision-making Process in Innovation Management - Application of AHP Method
}

\author{
Richard Jurenka ${ }^{1}$, Dagmar Cagáňová ${ }^{1}$, Daniela Špirková \\ Slovak University of Technology in Bratislava ${ }^{1,2}$, Faculty of Materials Science and \\ Technology in Trnava ${ }^{1}$, Institute of Industrial Engineering and Management ${ }^{1}$, \\ Institute of Management ${ }^{2}$, Slovakia ${ }^{1,2}$ \\ \{richard.jurenkalstuba.sk, dagmar.caganovalstuba.sk, \\ daniela.spirkovalstuba.sk\}
}

\begin{abstract}
The paper deals with the application of method - analytical hierarchy process in action of decision-making in the field of innovation management of industrial companies. Analytical hierarchy process is a tool for application of exact methods in process of decision-making. The paper contains theoretical description of analytical hierarchy process and subsequently also application of this method in the field of innovation management. Method of analytical hierarchy process brings into action of decision-making objectivity, exactness and also the quality of the evaluation. Perhaps the biggest advantage of this method is that this method allows to evaluate comprehensively all the criteria of alternative solutions. This paper aims to highlight the widespread use of method - analytical hierarchy process in the decision-making process, including in the field of innovation management.
\end{abstract}

Keywords: analytical hierarchy process, Expert Choice, innovation, innovation management, decision-making

\section{Introduction}

In the modern business environment, organizations must respond to new challenges, constant changes, opportunities and also must respond to the different requirements and various restrictions. Permanent transformation of the business environment are in contemporary world the necessity of continuous innovation and changes. Nowadays from existing organizations is expected some flexibility, dynamism and constant adaptation to changing conditions. The current social conditions are reflected in organizational behavior of individual companies and also in their decision-making process.

Social environment in this century is very dynamic, changeable, unstable and hardly predictable as a result for fewer and fewer areas is valid true stability or foreseeable development. Different changes in such an environment and conditions are becoming a necessity and everyday reality with which organizations must deal by their flexibility and ability to adapt to new and new conditions. In dynamic environment, in which organizations want to operate and develop is fundamental for 
companies constantly bringing new enhancements, innovations, ideas and thoughts. For selection the correct option of advancement is a necessary perfect decisionmaking process that will consider all the factors, risks and opportunities in outside and inside environment.

\section{Exact methods in managerial decision-making}

Decision-making is an integral part of management processes in every company and intersect across all functions of management - planning, organizing, staffing and maintaining staff, leadership people and controlling. All managers at all levels of directing make decisions, while the ultimate effect of these decisions can have a significant impact on a range of other activities. Some decisions are strategic in their nature and significantly affect company's survival on the market, others decisions can be seemingly pointless. However, all decisions have the certain impact on business performance, therefore is very important to give adequate attention to decisionmaking issue [1].

Decision-making as a complex process involves a number of different phases that must be met in order to have a final decision. Final decision is selected from several variants of solutions. Managers respectively competent persons have to make decisions even under changing conditions, under pressure, in a state of uncertainty or risk respectively under the influence of certain restrictions. The decision-making process is therefore a non-random selection of one variant of the solution according to certain criteria in order to meet pre-defined objectives.

\subsection{Decision-making process}

Decision-making process constitutes a comprehensive system which is characterized by the following parts:

- decision problem - is a reflection of the significant deviation between the desirable state (planned or established standards) of specific decision object and its real state;

- decision-making situations - is given by the object of decision (selected process or operation), by state of internal or external conditions which cause deviations from the desired state, by setting targets or its alternative aims, by criteria, variants and sometimes also consequences of possible decisions;

- decision-making process - the process of choosing between several possible solutions (search and selection of suitable alternatives solutions for the current problem);

- variations of decisions - option of several possible and different solutions which ideally suits to specific criteria [2].

Decision-making process is affected among other things, by ambient conditions, subject making decision, the object of decision-making, decision-making criteria and set goals. The following picture shows how the above-mentioned elements affect decision-making process (Fig. 1). 


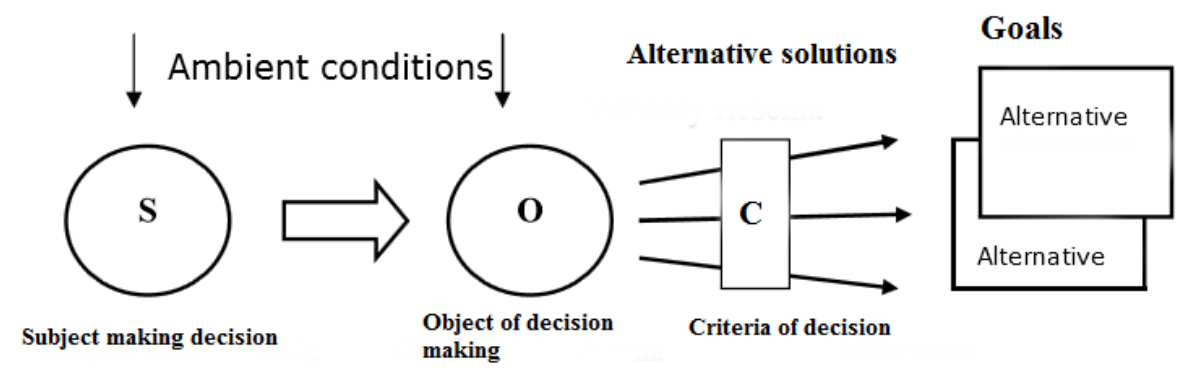

Fig. 1: Decision problem and decision making situations [2].

Necessary assumes for creating high-class decisions:

- clear statement of the target goal which must be achieved by decision;

- adequate, verified, quality, timely, reliable information that are the basis for making any high-grade decision;

- adequate qualification and competence of decision-makers. Using appropriate methods, tools and knowledge [3].

The following figure shows a decision algorithm:

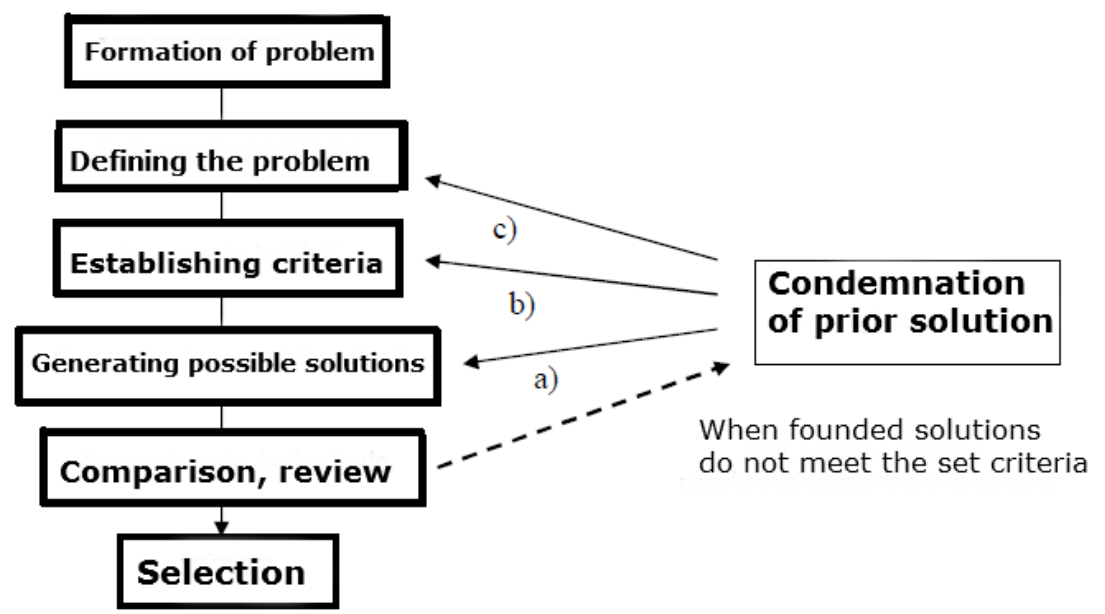

Fig. 2: Decision algorithm [2].

In business practice the decision-making process is not always as objective, uninfluenced by each successive steps, which are shown in Fig. 2, because a specific decision making process can be affected by in-house arrangements, conventions, stakeholder or under the influence of a supervisor person [4]. 


\subsection{Exact methods and Analytical hierarchy process (AHP)}

Exact methods of operational analysis can be classified among the most advanced quantitative methods for decision-making [5].

Analytical hierarchy process as a method provides a methodology that allows to model complex decision situation and determine the appropriate choices.

Although this method was not originally intended for collective decision-making, nowadays thanks to its transparency and consistency is using in situations of group decision [6].

Structured hierarchy of AHP method represent a system for optimization, which consists of a primary objective, criteria and alternatives, respectively in other words variations. The criteria can be further space out to sub-criteria, this division can lead to as many levels as it is necessary for resolving the problem.

AHP is a method of decomposition of complex unstructured situation into simpler components. This method is first done by an expert method and then by mathematical method, which divides the main problem into smaller and more detailed elements [7].

\subsection{Potential uses of AHP}

AHP method can be applied to decision-making processes, for assessment the aims in different sectors, but still there must be respected unless one conditions that decisionmaking must be set from at least two alternatives [8].

AHP method can be used in various fields as:

- management;

- logistics;

- economy;

- health care;

- education;

- research;

- agriculture and forestry;

- energy;

- transportation;

- industry.

\section{Application of AHP method in innovation management}

AHP method was used to select the most innovative variants. For application method of analytic hierarchy process was used software Expert Choice, which comprises from following steps:

1. Goal setting;

2. Determination of the individual criteria;

3. Assessment of alternative solutions;

4. The assignment of weights to each criterion;

5. Evaluation of the alternatives by paired comparison;

6. Reviewing the current state of the system of values. 
Goal setting - alternative (variants of) solutions in selecting the most appropriate innovation activity were selected six most used, innovative activities that are in the field of innovation management very often used. List of individual innovation activities respectively variants are as follows:

- Introduction of a new product;

- Modifying of the product;

- Change the size of the package;

- Change the appearance of a product (design);

- Amendments of the product;

- Introduction a new method of production.

Criteria for evaluation of possible alternatives solutions - for selection the most appropriate innovative variants were selected seven criteria. The criteria are actually kind of parameters of individual innovation activities. The criteria are given below:

- Price;

- Quality of manufacturing;

- Material;

- Appearance;

- Utilization;

- Durability;

- Energy consumption.

\subsection{Application of AHP method - use and application of Expert Choice}

Finding solution for our target goal to select the most innovative variant in innovation management was used computer software Expert Choice. Expert Choice software offers multi-criteria decision making process. Expert Choice offers the opportunity to split decisions in several hierarchical levels respectively sub-levels, thereby the entire decision-making process is divided into separate and simpler parts.

Such allocation is done through the tree structure which distributes and organize the entire hierarchy. Criteria and options are stored into the decision matrix. Individual preferences are granted according to Saaty nine point scale. Preferences can be given by numerical method or by verbal expression. Expert Choice offers evaluation by numerical or graphical representations. Our goal was by the AHP method find the most suitable alternative innovation activities. In order to find such a variant with computer software Expert Choice, at first we selected the main goal, at second we selected variants of innovation activities and then we entered the decisionmaking criteria. Target goal can be defined by clicking on the icon Goal.

\subsection{Defining criteria}

After setting the primary objective was the next step defining the decision-making criteria that represent a kind of basic parameters in the selection process of the best innovative variant or activity. Defined criteria are shown in Figure 3 (Price, Quality of manufacturing, Material, Appearance, Utilization, Durability and Energy consumption). 


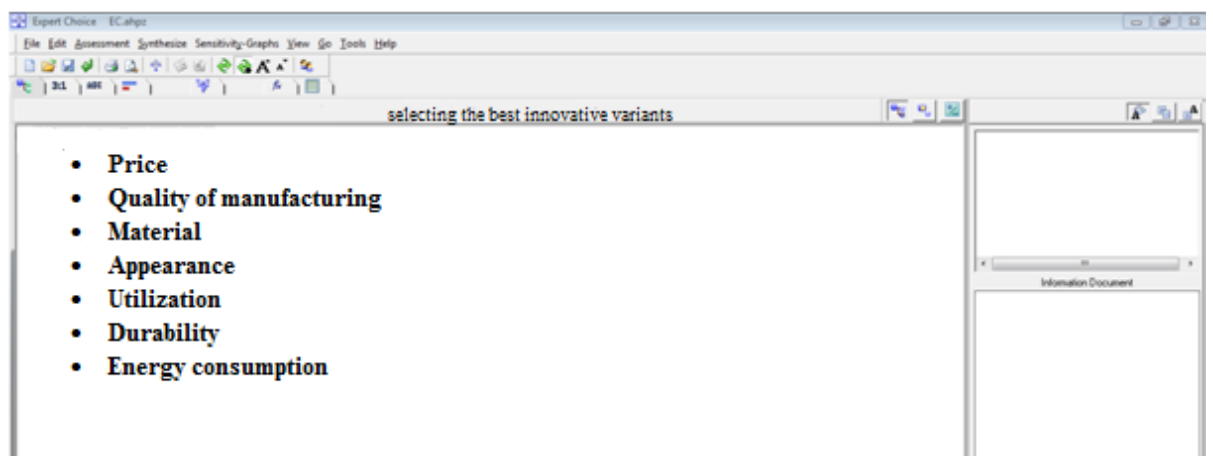

Figure 3: The file of decision criteria

\subsection{Assessment of alternative variants}

The next step in the application was to determine the individual variants of innovation activities, which are used in the field of innovation management.

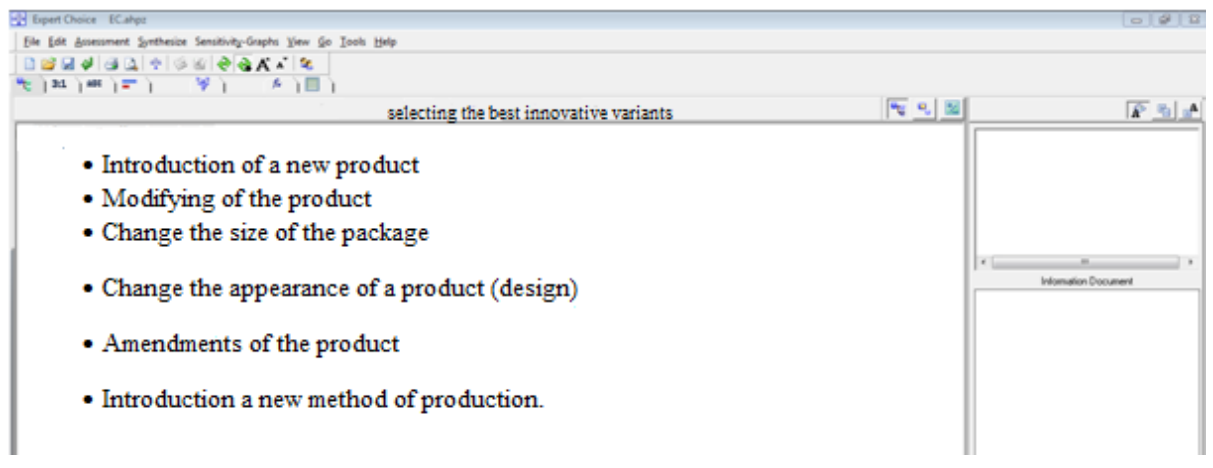

Fig. 4: Determination of the individual variants

\subsection{Assignment of weights to variants and to individual criteria}

The next task was to determine specific values for the selected variants in accordance with the established criteria. The allocation of weights to each variant and criterion is undoubtedly an important step in the whole process. For the objectivity and better results of calculation the best innovative activities the individual values in the table were determined by two experts in the field.

Consequently, it is necessary to compare each individual variant with other and do the same comparison between each criteria with each other. This comparison is performed separately for each variant and criterion. The procedure is identical in Expert Choice and this software can provide for us verbal, numerical respectively graphical representation of a particular comparison. The following Fig. 5 shows the assignment of values for them. 


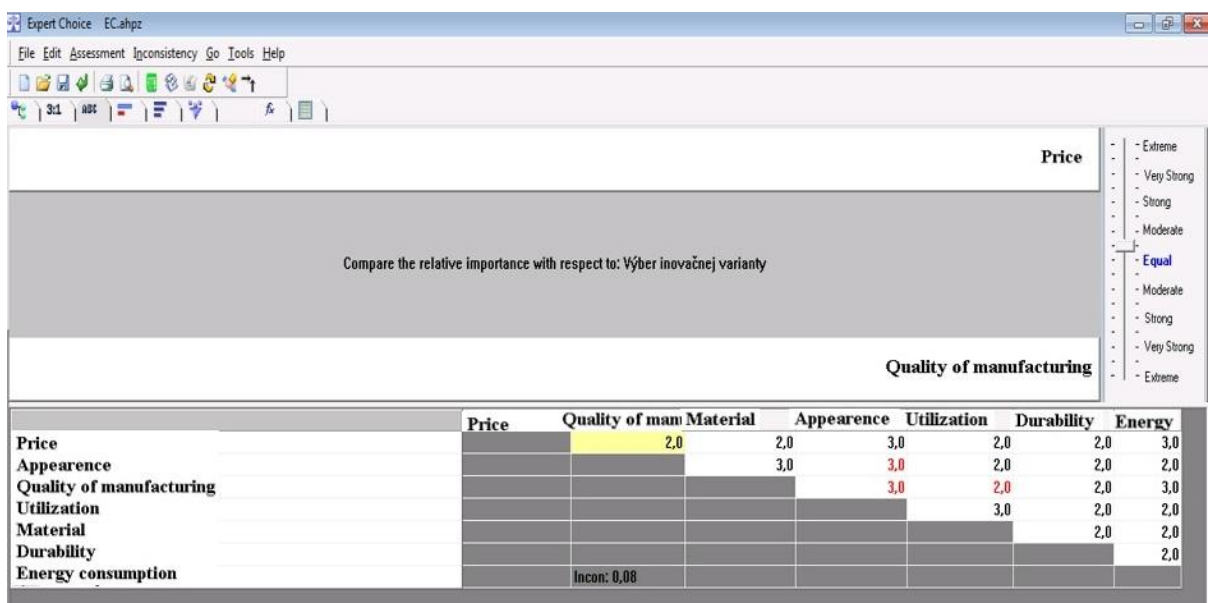

Fig. 5: Entering the values to individual criteria

Word comparison of criteria (Fig. 5) is performed by verbal designation. The relationship between each criteria (or variation) can be equal, moderate, strong, very strong or extreme.

\subsection{Evaluation of paired comparison of all criteria}

After the successful assignment of particular values to compared criteria is possible to determined which criterion is most important for us as well which criterion is at least important in concrete decision-making process. On the following Fig. 6 is displayed graph which tell us that price criterion is the most important criterion from all criteria in process of choosing the best innovation activity. Consequently, it is possible to see the order of the other criteria importance.

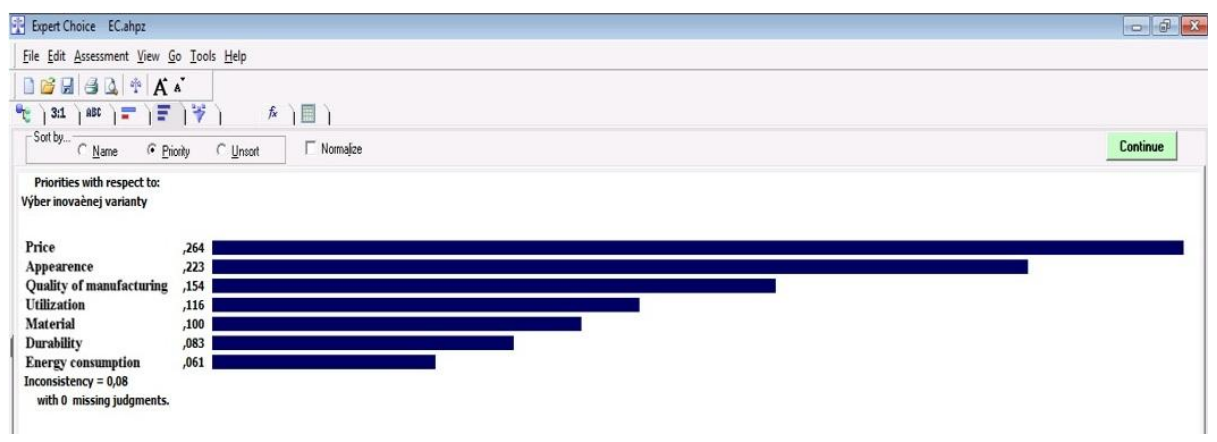

Fig.6: Graphical comparison of the most important criteria in process of choosing the best innovation activity 


\subsection{Final evaluation}

The final evaluation is the ending phase. By the paired comparison of variations and criteria with software Expert Choice that gave us a result, in the form of various graphs respectively diagrams. Final evaluation can be either numerical or graphical. In this project was selected the main goal as selecting the most innovative variant or activity. Evaluation of the whole process which was realized in Expert Choice can be seen in the following Fig. 7 that gives us graphic and numerical information. From the figure can be revealed that the most important criterion is price and most important variant was chosen introduction of a new product.

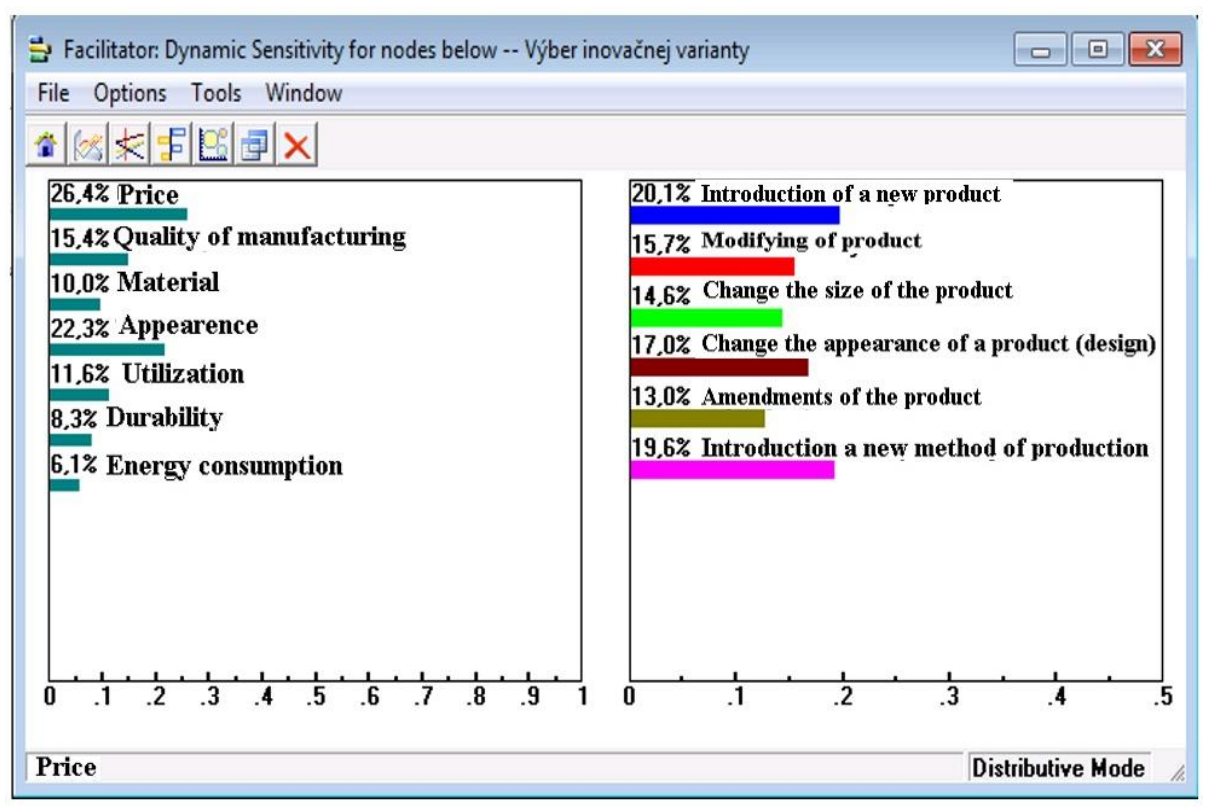

Fig. 7: Percentage evaluation of individual criteria and variation

The above mentioned Figure shows in detail the results of the percentage of the whole evaluation. As from the Figure results that the most important criterion for choosing the best innovation activity is the price with $26.4 \%$. The second most important criterion is the design, which is reflected by $22.3 \%$. Next follow the criteria of quality of manufacturing with $15,4 \%$, the criterion utilization with $11.6 \%$, material with $10.0 \%$. Durability has $8.4 \%$ and the least important criterion was chosen the energy consumption with $6.1 \%$.

Final evaluation of variants with regard to the selected criteria determined as the most significant innovation activity introduction of a new product, this statement is represented by $20.1 \%$. The most important innovation activity is followed by the introduction of a new process for the production, this activity was very close and its importance is reflected with $19.6 \%$. On third place is located the change of design with $17.0 \%$. This activity is followed by modifying the product with $15,7 \%$, change of 
the size of package is represented by $14.6 \%$ and in last place in terms of the attractiveness of innovative activities are amendments of product with $13.0 \%$.

\section{Conclusion}

The article discusses and describes how the program Expert Choice works. Expert choice applies the method of analytic hierarchy process in business practice. Application of AHP method was performed in decision-making processes falling into the field of innovation management, in this case the application of AHP method is an ideal tool for selecting the most suitable variants. AHP method as a method of multicriteria decision making can work with a number of criteria. In this paper we managed to choose the most innovative options, namely the introduction of a new product with an assistance of software program Expert Choice. The aim of the project and the article was to point out the large-scale use of AHP method.

Final evaluation shows us that the most important criterion for choosing the best innovation activity is the price with $26.4 \%$. Final evaluation of variants with regard to the selected criteria determined as the most significant innovation activity introduction of a new product, this statement was expressed by the $20.1 \%$. The work itself is served to general public and by simply way explains AHP method and the using of software Expert Choice, which can be used in many sectors within the decision-making process.

\section{References}

1. ČAMBÁl, M., HOLKOVÁ, A., LENHARDTOVÁ, Z. 2011. Základy manažmentu. Bratislava Alumni Press. ISBN 978-80-8096-138-1

2. UNIZA. Rozhodovacie procesy. [online]. Accessible at: http://fsi.uniza.sk/kkm/old/publikacie/ma/ma_05.pdf

3. MÁCA, J., LEITNER, B. 2002. Operačná analýza I.: Deterministické metódy operačnej analýzy. [online]. Accessible at: http://fsi.uniza.sk/ktvi/publikacie/11_operanal1_u_2002.pdf

4. BAĎO, R., VRABLIC, P. 2011. Využitie metódy multikriteriálneho rozhodovania metódou AHP pri rozhodovani v podnikatel'skom prostredí. Transfer informácii 21/2011. Bratislava: Strojnícka fakulta STU. [online]. Accessible at: <http://www.sjf.tuke.sk/transferinovacii/pages/archiv/transfer/21-2011/pdf/082-085.pdf>

5. HRABLIK CHOVANOVÁ, H., SAKÁL, P., DRIENIKOVÁ, K., NAŇO, T. 2012. Operačná analýza : čast’ II. Trnava: AlumniPress. ISBN 978-80-8096-165-7

6. RAMÍK, J. 2010. Analytický hierarchický proces (AHP) a jeho možnosti uplateněni při hodnocení a podpoře rozhodování.v Sborniku př́spěvku $z$ konference: Matematika $v$ ekonomické praxi. Jihlava. [online]. Accessible at: < https://most.vspj.cz/files/11/Matematikav-ekonomicke-praxi.pdf>

7. DRIENIKOVÁ. K. et al. VYUŽITIE AHP METÓDY PRI TVORBE UDRŽATEL'NEJ STRATÉGIE SZP - I. (ANALYTICKÝ HIERARCHICKÝ PROCES) [online]. Accessible at: http://www.scss.sk/cd_apvv_lpp_0384_09_2011/V\%C3\%9DSTUPY\%20Z\%20VLASTNEJ\%2 OVEDECKO-

V\%C3\%9DSKUMNEJ\%20A\%20PEDAGOGICKEJ\%20\%C4\%8CINNOSTI/PUBLIKA\%C4 $\% 8 \mathrm{CN} \% \mathrm{C} 3 \% 81 \% 20 \% \mathrm{C} 4 \% 8 \mathrm{CINNOS} \% \mathrm{C} 5 \% \mathrm{~A} 4 / \mathrm{KONFERENCIE/BRNO/I..pdf}$

8. ROHÁČOVÁ, I., MARKOVÁ, Z. 2009. Analýza metódy AHP a jej potenciálne využitie $v$ logistike. [online]. Acta Montanistica Slovaca Ročník 14 (2009), číslo 1, 103-112. 